\title{
New Korean record of the Banded Driftfish, Psenes arafurensis (PISCES: Nomeidae)
}

\author{
Woo Jun Lee ${ }^{1}$, Jung-Hwa Ryu ${ }^{2}$, Moongeun Yoon ${ }^{3}$, Hye Suck $\mathrm{An}^{3}$, Jiyoung Woo ${ }^{3}$, Fumihito Tashiro ${ }^{4}$ \\ and Jin-Koo Kim ${ }^{1 *}$ (D)
}

\begin{abstract}
Psenes arafurensis, belonging to the family Nomeidae, is described based on four specimens (184.8-199.0 mm in standard length) collected from Korea. The species is most similar to the congeneric species $P$. maculatus and $P$. pellucidus, but differs from them in the number of lateral-line scales. (44-47 in $P$. arafurensis vs 67-70 in $P$. maculatus and 120 in $P$. pellucidus) and the number of vertebrae (31 in $P$. arafurensis vs 34-38 in $P$. maculatus and 40-42 in P. pellucidus). The present study is a new record of $P$. arafurensis with voucher specimens from Korean waters.
\end{abstract}

Keywords: Psenes arafurensis, Nomeidae, New record, Korea

\section{Background}

The family Nomeidae in the order Perciformes contains three genera and 16 species worldwide (Nelson 2006), of which three genera and nine species occur in Japan (Nakabo and Doiuchi 2013) and two genera and four species occur in Korea (Cubiceps squamiceps, Psenes cyanophrys, P. maculatus and P. pellucidus) (Kim 2011). Of these, two species (P. cyanophrys and P. maculatus) were first reported from Korea by Myoung et al. (2001). Myoung et al. (2002) reported $P$. arafurensis as a new Korean nomeid fish, and suggested the new Korean name "A-ra-pu-ra-dom", but no morphological description of $P$. arafurensis was given. Therefore, we cannot confirm that the species occurs in Korean waters, and the morphological traits of Korean $P$. arafurensis remain unknown. Recently, we collected four specimens of $P$. arafurensis from various localities in Korea. Here, we describe the morphology of these $P$. arafurensis specimens and confirm their taxonomic status using molecular analysis.

\section{Methods}

Four specimens were collected using a purse seine net from three localities in Korean waters (Jejudo

\footnotetext{
* Correspondence: taengko@hanmail.net

'Department of Marine Biology, Pukyong National University, Busan 48513, Korea

Full list of author information is available at the end of the article
}

Island, Yeonggwang and Gunsan), between August and September, 2013 and in September, 2014 (Fig. 1). Counts and measurements were made according to Regan (1902) and Hubbs and Lagler (2004). The numbers of vertebrae were counted from radiographs (Hitex HA-100; Hitex Co., Tokyo, Japan). The specimens were deposited in the Ichthyology Laboratory of Pukyong National University (PKU), Korea.

Genomic DNA was extracted from muscle tissue using Chelex 100 resin (Bio-Rad, Hercules, California, USA) and polymerase chain reaction (PCR) was conducted using a universal primer set to amplify the mitochondrial DNA (mtDNA) cytochrome c oxidase subunit I gene (COI) (Ward et al. 2005; Ivanova et al. 2007). We also obtained the mitochondrial COI sequences of three Nomeidae species from the National Center for Biological Information (NCBI) database. The sequences were aligned using ClustalW (Thompson et al. 1994) in BioEdit (ver. 7) (Hall 1999). A neighbor-joining (NJ) tree (Saitou and Nei 1987) was constructed using the Kimura two-parameter model (Kimura 1980) in MEGA 5 (Tamura et al. 2011). We submitted the nucleotide sequence data of these specimens to the NCBI.

\section{Material examined \\ PKU 9645, 1 specimen, $185.6 \mathrm{~mm} \mathrm{SL}, 33^{\circ} 67.99^{\prime} \mathrm{N}, 127^{\circ}$ $47.85^{\prime}$ E, Jeju-si, Jejudo Island, Korea, August 2013; PKU 9855, 1 specimen, $194.0 \mathrm{~mm} \mathrm{SL}, 35^{\circ} 32.80^{\prime} \mathrm{N}, 125^{\circ} 58.99^{\prime}$}




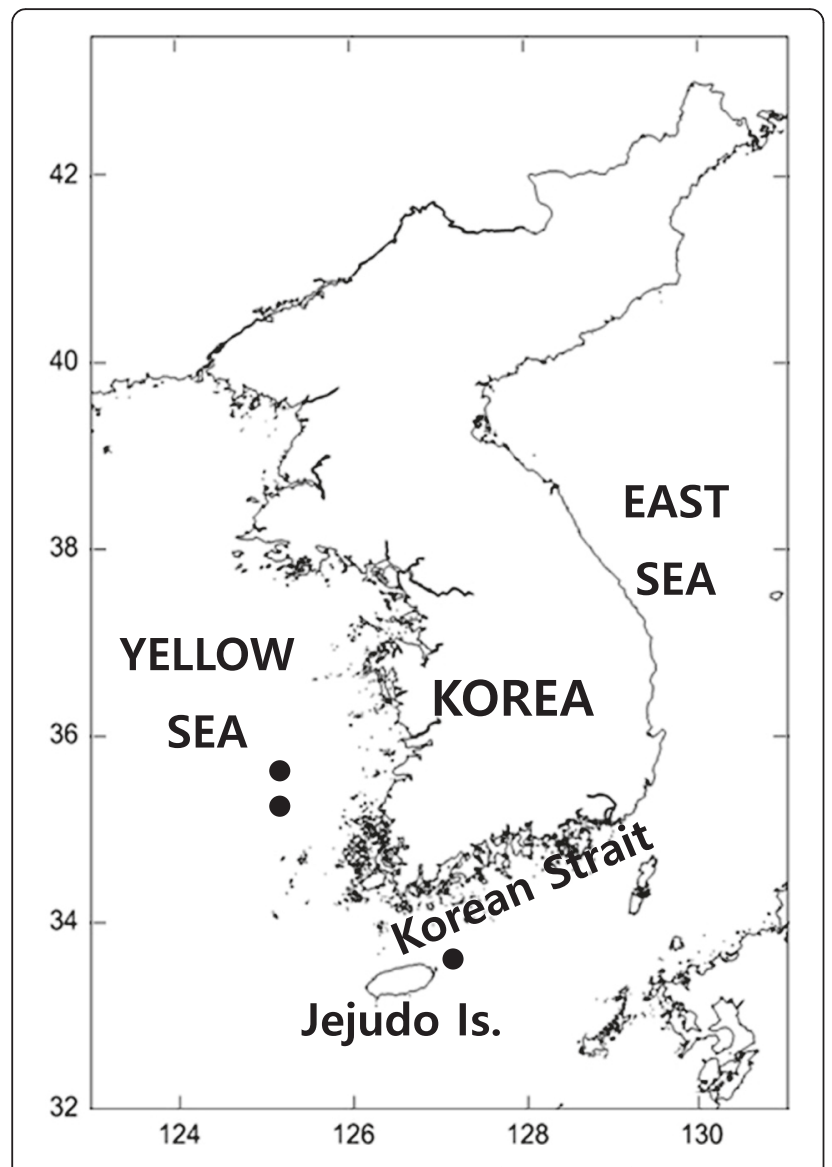

Fig. 1 Map showing the sampling sites of Psenes arafurensis

E, Yeonggwang-gun, Jeollanam-do, Korea, September 2013; PKU 9949, 1 specimen, 199.0 mm SL, 3595.89' N, $125^{\circ}$ 65.04'E, Gunsan-si, Jeollabuk-do, Korea, September 2013; PKU 11311, 1 specimen, 184.8 mm SL, 3367.99' N, $127^{\circ} 47.85^{\prime}$ E, Jeju-si, Jejudo Island, Korea, September 2014. Additional muscle tissues used for molecular analysis: FAKU 130210 (muscle tissue was transferred to PKU 12385), Oki Island, Shimane Prefecture, Japan, August 2003; FAKU 132174 (muscle tissue was transferred to PKU 12386), Chitose, Maizuru, Kyoto, Japan, November 2009.

\section{Results and discussion}

\section{Psenes arafurensis Günther, 1889}

(Korean name: A-ra-pu-ra-dom)

(Fig. 2; Table 1)

Psenes arafurensis Günther, 1889: 13 (type locality: Arafura Sea, western Pacific); Kuiter 1993: 381 (Australia); Bianchi et al 1993: 176 (Namibia); Chirichigno and Vélez 1998: 291 (Peru); Randall and Lim 2000: 644 (South China Sea); Myoung et al. 2002: 222 (Jejudo Island and South Sea of Korea); Nakabo 2002: 963 (Japan); Menezes et al. 2003: 104 (Brazil); Parin and Piotrovsky 2004: S51 (Indian

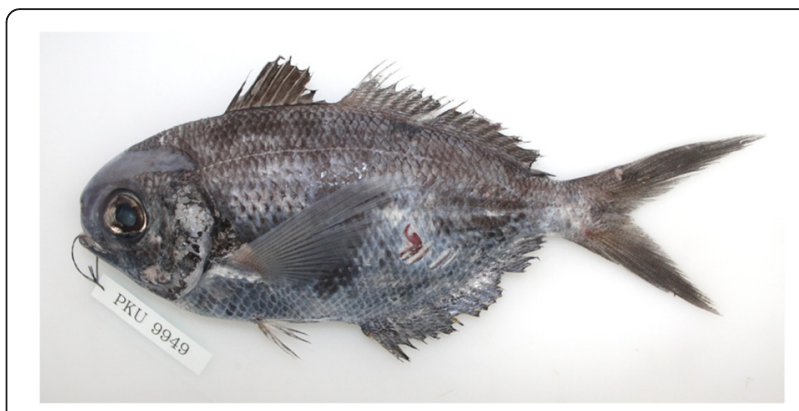

Fig. 2 Psenes arafurensis, PKU 9949, 199.0 mm SL, Gunsan-si, Jeollabuk-do, Korea

Ocean); McEachran and Fechhelm 2005: 807 (Mexico); Allen and Erdmann 2012: 1042 (East Indies).

Psenes benardi Rossignol and Blache, 1961: 384 (Guinea).

\section{Description}

Dorsal fin rays XI-I, 20-21; pectoral fin rays 19-20; anal fin rays III, 21-22; lateral-line scales 46-48; gill rakers 25-27; vertebrae 30-31. Meristic and morphometric characters are shown in Table 1. Body ovate, deep [41.5$44.8 \%$ standard length (SL)], and compressed. Head large (30.5-33.3 \% SL); eyes large (28.8-31.2\% of head length); snout rounded and short; two pairs of nostrils located nearer to tip of snout than to eye. Mouth terminal; upper jaw oblique, posterior margin not reaching to middle part of eye; teeth on jaws small and conical in a single row. Lateral line slightly arched, located nearer to dorsal part of body than to middle part of body. Two dorsal fins separated from each other by a narrow space; first dorsal fin beginning at base of pectoral fin, reaching anus; second dorsal fin beginning at anus, reaching anterior caudal peduncle, base length of first dorsal fin much shorter than that of second dorsal fin; two fins of similar depth. Anal fin origin slightly behind origin of second dorsal fin; spines of anal fin weak. Pectoral fin origin slightly anterior to the origin of pelvic fin, reaching to 9-10th second dorsal fin rays. Pelvic fin short, reaching to origin of second dorsal fin. Caudal fin long and strongly forked. Caudal peduncle short (4.5-4.9\% SL) and compressed. Body, head and cheeks covered with relatively large ctenoid scales.

\section{Coloration}

When fresh, the dorsal surfaces of the head and body are dark purple, the ventral surfaces are gray, dorsal and caudal fin dark gray; pectoral fins translucent; pelvic fins and anal fin gray. After fixation, the dorsal surfaces of the head and body are dark brown, the ventral surfaces are gray brown, fin color as for fresh specimens. 
Table 1 Comparison of counts of Psenes arafurensis among authors

\begin{tabular}{|c|c|c|c|c|}
\hline Characters & Present study & Günther (1889) & Regan (1902) & Nakabo and Doiuchi (2013) \\
\hline Number of specimens & 4 & 1 & 1 & - \\
\hline Total length (mm) & $249.5-270.1$ & 38.1 & - & \\
\hline Fork length & $201.8-219.7$ & - & - & - \\
\hline Standard length & $184.8-199.0$ & - & 30 & 150.0 \\
\hline \multicolumn{5}{|l|}{ In \% of standard length } \\
\hline Head length & $30.5-33.3$ & 37.5 & 40.0 & - \\
\hline Body depth & $41.5-44.8$ & 60.0 & 60.0 & - \\
\hline Preanal length & $57.0-59.3$ & - & - & - \\
\hline Caudal peduncle length & $10.3-10.6$ & - & - & - \\
\hline Caudal peduncle depth & $4.5-4.9$ & - & - & - \\
\hline Eye diameter & $9.0-10.4$ & - & - & - \\
\hline \multicolumn{5}{|l|}{$\%$ of head length } \\
\hline Eye diameter & $28.8-31.2$ & 40.0 & 37.5 & - \\
\hline Snout length & $29.5-31.9$ & 16.7 & 16.7 & - \\
\hline Interorbital space & $37.6-41.9$ & - & & - \\
\hline Upper jaw length & $31.3-34.2$ & - & - & - \\
\hline Caudal peduncle depth & $13.4-15.5$ & - & - & - \\
\hline \multicolumn{5}{|l|}{ Meristic characters } \\
\hline Dorsal fin rays & XI-I, 20-21 & VII ?, 20 & $X I-I, 22$ & X-XI-I-II, 19-21 \\
\hline Anal fin rays & III, 21-22 & III, 22 & III, 22 & III, 20-21 \\
\hline Pelvic fin rays & 1,5 & - & ।, 5 & \\
\hline Pectoral fin rays & $19-20$ & - & - & $18-20$ \\
\hline Scales in lateral line & $46-48$ & 47 & $473 / 20$ & $44-45$ \\
\hline Gill rakers & $25-27$ & - & & - \\
\hline Vertebrae & $30-31$ & - & 31 & - \\
\hline
\end{tabular}

\section{Distribution}

This species is found in the tropical and subtropical seas of the Pacific, Indian and Atlantic Oceans, at depths of 150-850 m (Nakabo and Doiuchi 2013), and off Jejudo Island at the eastern margin of the Yellow Sea and the Korean Strait (present study).

\section{Remarks}

These four specimens collected from Korean waters are similar to Psenes arafurensis, P. cyanophrys, P. maculatus and $P$. pellucidus in having a short snout (29.5$31.9 \%$ head length) and fewer scales in the lateral line (46-48) (Nakabo and Doiuchi 2013). These four species can be distinguished easily from each other by differences in the number of lateral line scales (44-47 in $P$. arafurensis, 60-63 in P. cyanophrys, 67-70 in P. maculatus and 120 in $P$. pellucidus) and vertebrae (31 in $P$. arafurensis, 30-31 in P. cyanophrys, 34-38 in P. maculatus and 40-42 in P. pellucidus); the present specimens resemble $P$. arafurensis closely, having 44-47 lateral line scales and 31 vertebrae (Abe et al. 1963; Heemstra 1986;
Nakabo and Doiuchi 2013). However, the number of dorsal fin spines in these specimens is obviously different from the original description of $P$. arafurensis [11 in the present specimens vs. 7 in Günther (1889)], although other counts entirely correspond with the present study. Regan (1902) pointed out the miscount of this character by Günther (1889) and indicated that the actual number is 11 . According to this correction, the number of dorsal fin spines of the present specimens is also congruent with the holotype of $P$. arafurensis. However, several morphometric differences were observed between the present four specimens and the holotype shown by Günther (1889) and Regan (1902) (Table 1). Proportional changes with growth, especially between young and subadult stages, are generally known in the nomeid fishes (Haedrich 1967), and the body sizes of the present specimens (184.8-199.0 mm SL) are much larger than that of the holotype (30 mm SL). Therefore, we concluded that these morphometric differences are intraspecific variations caused by body size differences. So, to identify the species more accurately, we analyzed 562 base pairs of 


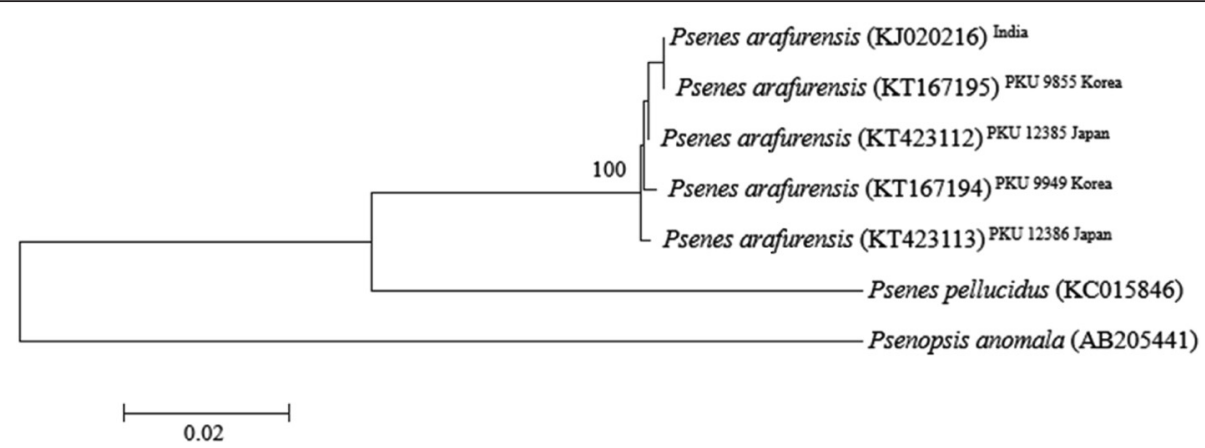

Fig. 3 Neighbor-joining tree constructed by the mitochondrial DNA COI sequences of Psenes arafurensis, with two outgroups (Psenes pellucidus and Psenopsis anomala). Numbers at branches indicate bootstrap probabilities in 1000 bootstrap replications. Bar indicates genetic distance of 0.02

the mtDNA COI sequence. The mtDNA COI sequence determined in this study is nearly identical to the sequences of Indian and Japanese $P$. arafurensis (genetic distances, $d=0.002-0.004$ ) (Fig. 3). Therefore, these morphological differences seem to be intraspecific variations. Since a Korean name, "A-ra-pu-ra-dom", for $P$. arafurensis has already been proposed by Myoung et al. (2002), we also adopted this name for the species.

\section{Conclusions}

Four specimens of nomeid fish were collected in Korean waters (Jejudo Island, Yeonggwang and Gunsan), between August and September, 2013 and in September, 2014. These specimens were identified as belonging to Psenes arafurensis, based on numbers of short snout (29.5-31.9 \% head length), vertebrae (31) and fewer scales in the lateral line (46-48). An analysis of 562 base pair sequences of mitochondrial DNA cytochrome c oxidase subunit I showed that sequences in our specimens are concordant with those of $P$. arafurensis from the India, and Japan (genetic distance $=0.002-0.004$ ).

\section{Competing interests}

The authors declare that they have no competing interests.

\section{Authors' contributions}

WJL and JHR wrote the manuscript. MGY, HSA and JYW carried out the molecular genetic experiments. FT offering Japanese specimens and data. JKK suggested all aspects of study design, and commented on the earlier drafts of the manuscript. All authors read and approved the final manuscript.

\section{Acknowledgments}

We sincerely thank to anonymous reviewers for their valuable comments. This work was supported by National Marine Biodiversity Institute Research Program (2015 M00500).

\section{Author details}

'Department of Marine Biology, Pukyong National University, Busan 48513, Korea. ${ }^{2}$ Ryujunghwa Marine Research Institute, Busan 47323, Korea. ${ }^{3}$ Marine Biodiversity Institute of Korea, Seocheon-gun, Chungcheongnam-do 33662, Korea. ${ }^{4}$ Maizuru Fisheries, Research Station, Field Science Education and Research Center, Kyoto University, Maizuru, Kyoto 625-0086, Japan.

\section{References}

Abe T, Kojima S, Kosakai T. Description of a new nomeid fish from Japan. Jpn Ichythyol. 1963;11:31-5.

Allen GR, Erdmann MV. Reef fishes of the East Indies. Volumes I-III. Perth: Tropical Reef Research; 2012. p. 1042.

Bianchi G, Carpenter KE, Roux JP, Molloy FJ, Boyer D, Boyer HJ. FAO Species Identification Field Guide for Fisheries Purposes. The Living Marine Resources of Namibia. Rome: FAO; 1993. p. 176.

Chirichigno FN, Vélez J. Clave para identificar los pecesmarinosdel Peru (Seguendaedición, revidada y actualizada). Lima: Instituto del Mar del Peru, Publicación especial; 1998. p. 291.

Günther A. Report on the pelagic fishes collected by H. M. S. Challenger during the years 1873-76. Report on the Scientific Results of the Voyage of H. M. S. Challenger, vol. 31. 1889. p. 1-47.

Haedrich RL. A New Species of Psenopsis (Stromateoidei, Centrolophidae) from Indo-Malayan Seas. Jpn Ichythyol. 1967;14:187-96.

Hall TA. BioEdit: a user-friendly biological sequence alignment editor and analysis program for Windows 95/98/NT. Nucleic Acids Symp Ser. 1999;41:95-8.

Heemstra PC. Family Nomeidae. In: Smith MM, Heemstra PC, editors. Smith's sea fishes. Grahamstown: Springr-Verlag; 1986. p. 846-50.

Hubbs CL, Lagler KF. Fishes of the Great Lakes Region. Revised ed. Ann Arbor: University of Michigan Press; 2004

Ivanova NV, Zemlak TS, Hanner RH, Hebert PDN. Universal primer cocktails for fish DNA barcoding. Mol Ecol Notes. 2007;7:544-8.

Kim BJ. Fish species of Korea. In: National List of species of Korea: Vertebrates. Incheon: National Institute of Biological Resources; 2011. p. 168-9.

Kimura M. A simple method for estimating evolutionary rates of base substitutions through comparative studies of nucleotide sequences. J Mol Evol. 1980;16:111-20.

Kuiter RH. Coastal fishes of south-eastern Australia. Honolulu: University of Hawaii Press; 1993. p. 381.

McEachran JD, Fechhelm JD. Fishes of the Gulf of Mexico. Volume 2: Scorpaeniformes to Tetraodontiformes. Austin: University of Texas Press; 2005. p. 807.

Menezes NA, Buckup PA, de Figueiredo JL, de Moura RL, editors. Catálogo das espécies de peixesmarinhos do Brasil. São Paulo: Museu de Zoologia de Universidade de São Paulo; 2003. p. 104.

Myoung JG, Cho SH, Kim JM, Kim YU. First record of the two driftfish, Psenes maculatus, and Psenes cyanophrys (Nomeidae: Perciformes) from Korea. Korean J Ichythyol. 2001;13:195-200.

Myoung JG, Kim BI, Lee SM, Jeon GB. The sea fishes of Korea. Seoul: Daragwon; 2002. p. 222.

Nakabo. Nomeidae. In: Fishes of Japan with pictorial keys to the species, English edition. Tokyo: Tokai University Press; 2002. p. 963-5.

Nakabo, Doiuchi. Nomeidae. In: Fishes of Japan with pictorial keys to the species. Tokai University Third edition. Tokyo: Tokai University Press; 2013. p. 1081-3.

Nelson JS. Fishes of the World. 4th ed. Hoboken: John Wiley \& Sons, Inc; 2006. p. 436.

Parin NV, Piotrovsky AS. Stromateoid fishes (suborder Stromateoidei) of the Indian Ocean (species composition, distribution, biology, and fisheries). J Ichythyol. 2004;44:33-62. 
Randall JE, Lim KKP. A checklist of the fishes of the South China Sea. Raffles B Zool Suppl. 2000;8:569-667.

Regan CT. A revision of the fishes of the family Stromateidae. Ann Mag Nat Hist. 1902:10(115-131):194-207.

Rossignol M, Blache J. SUR UN POISSON STROMATEIDAE NOUVEAU DU GOLFE DE GUINÉE. PSENES BENABDI NOV. SP. Bulletin du Muséum National d'Histoire Naturelle. 2e Série. 1961;33:384-386.

Saitou N, Nei M. The neighbor-joining method - a new method for reconstructing phylogenetic trees. Mol Biol Evol. 1987;4:406-25.

Tamura K, Peterson D, Peterson N, Stecher G, Nei M, Kumar S. MEGA5: molecular evolutionary genetics analysis using maximum likelihood, evolutionary distance, and maximum parsimony methods. Mol Biol Evol. 2011;28:2731-9. Thompson JD, Higgins DG, Gibson TJ. CLUSTAL W: improving the sensitivity of progressive multiple sequence alignment through sequence weighting, position-specific gap penalties and weight matrix choice. Nucleic Acids Res. 1994;22:4673-80.

Ward RD, Zemlac TC, Innes BH, Last PR, Hebert PDN. DNA barcoding Australia's fish species. Philos Trans Biol Sci. 2005;360:1847-57.

\section{Submit your next manuscript to BioMed Central and we will help you at every step:}

- We accept pre-submission inquiries

- Our selector tool helps you to find the most relevant journal

- We provide round the clock customer support

- Convenient online submission

- Thorough peer review

- Inclusion in PubMed and all major indexing services

- Maximum visibility for your research

Submit your manuscript at www.biomedcentral.com/submit 